\title{
Influence of Occupational Stress (Occupational Role Stress) on Organizational Commitment: Evidence from the Banking Sector of Karachi
}

\section{Tooba Atif ${ }^{1}$ \\ Shameel Ahmed Zubairi Sheeba Farhan ${ }^{\star \star}$}

'PhD Scholar Department of Public Administration University of Karachi, Pakistan. Email:Write2tooba@gmail.com Tel:03332684749

-Assistant Professor at Karachi Business School (KUBS) University of Karachi, Pakistan. Email:sazubairi@uok.edu.pk

${ }^{3}$ Assistant Professor at Department of Psychology Bahria University, Pakistan.

Email:Sheebafarhan2012@gmail.com Tel:03002455876

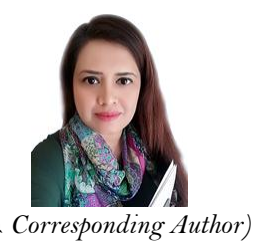

\begin{abstract}
It is frequently observed that stress has appeared to be one of those influential factors that have critical impacts on human life; especially, the performance of a person, which is the key aspect of human life, is impacted by stress. The purpose of this research was to extend the existing body of knowledge on the relationship between occupational stress and employees' organizational commitment into the context of banking sector of Pakistan. This qualitative study is comprise of 303 respondents The statistical techniques that were used were Exploratory factor analysis (EFA), Confirmatory factor analysis (CFA) and Structural equation modeling (SEM). Employees were analyzed for their affective commitment, continuance commitment and normative commitments. Results shows that there is a positive or significant relationship between occupational role stress and affective commitments of employees, which implied that higher score on occupational role stress prompted lower score on affective occupational commitment of the Bank representatives. It was likewise discovered that the way of association additionally influenced the relationship between occupational role stress and other two types of organizational commitments i.e. continuance and normative commitments of employees. The level of significance for employees working in banking sectors of Pakistan was found to be insignificant for continuance and for normative commitment. These results approved that there is an opposite relationship between occupational role stress and normative and continuance commitment as compared to affective job responsibility of employees.
\end{abstract}

Keywords: Occupational stress, Occupational role stress, Organizational commitment, CFA, EFA, SEM.

JEL Classification: Mental health, Banking, Stress, Organizational commetment.

Citation | Tooba Atif; Shameel Ahmed Zubairi; Sheeba Farhan (2020). Influence of Occupational Stress (Occupational Role Stress) on Organizational Commitment: Evidence from the Banking Sector on Organizational Commitment: Evidence from the Banking Sector
of Karachi. Asian Journal of Social Sciences and Management Studies, 7(4): 271-279.

History:

Received: 6 August 2020

Revised: 15 September 2020

Accepted: 30 September 2090

Accepted: 30 September 2020

Published: 13 October 2020

Attribution 3.0 License (cc)

Publisher: Asian Online Journal Publishing Group
Acknowledgement: All authors contributed to the conception and design of the study.

Funding: This study received no specific financial support

Competing Interests: The authors declare that they have no conflict of interests.

Transparency: The authors confirm that the manuscript is an honest, accurate, and transparent account of the study was reported; that no vital features of the study have been omitted; and that any discrepancies from the study as planned have been explained.

Ethical: This study follows all ethical practices during writing.

\section{Contents}

1. Introduction

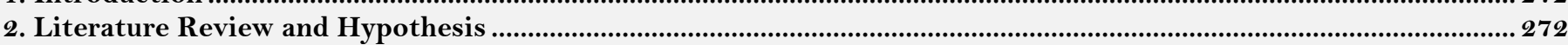

3. Methodology

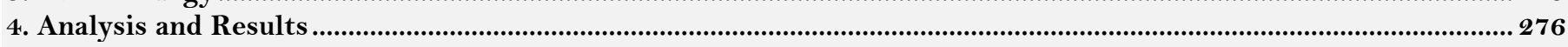

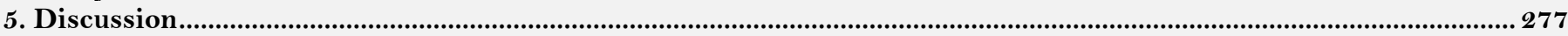

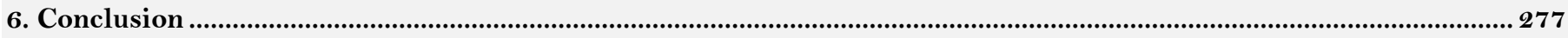

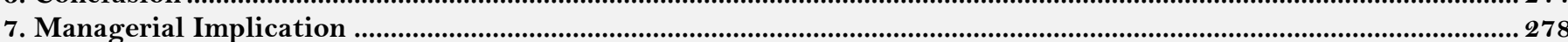

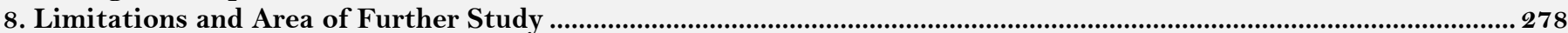

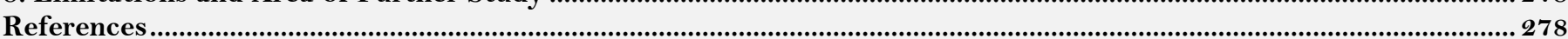




\section{Contribution of this paper to the literature}

This paper discusses influence of occupational stress (occupational role stress) on organizational commitment among bankers of city Karachi. As bankers have too much responsibilities on their shoulders that ultimately makes the job more stressful. The occupational role stress is one of the factor that effects organizational commitment of bankers. Hence the study indirectly highlights the importance of organizational commitment and it will also fill the gap in the literature that can help the bankers in making strategies and further decisions.

\section{Introduction}

This research analyzes the influence of occupational stress on organizational commitment in the banking sector in Pakistan. Occupational role stress is one of the components of occupational stress. Banking industry is usually the most important industry of any country. Like many other countries, Pakistan is also grappling with several issues, changes, developments, challenges and problems in the banking industry. In the history of banking, there have been significant changes in policies, management and organization during last decades.

Work place commitment among the employees is decreasing day by day. Psychological factors are contributing a lot in creating disturbance and restlessness among workers. Among the different psychological issues, most distracting and off-putting phenomenon is stress at work, which is often called occupational stress.

Cartwright and Cooper (1997) presumed that occupational stress is a solid indicator of organizational commitment. Kobasa and Antrosrusky (1998) have additionally affirmed the huge relationship between occupational stress and occupational commitment. According to Hashmi and Naqvi (2012) turnover of banks in the earlier years was at its peak but it is the low organizational commitment that banking sectors had to face that drove down the profits.

In response to the lack of empirical literature investigating occupational stress (occupational role stress) and organizational commitment, the goals of this study is to explore the relationship between organizational commitment and the occupational stress (occupational role stress). Firstly, an exploratory study was undertaken, based on the links established in Study, the influence of occupational stress (occupational role stress) on the overall commitment towards organization will be determined. Studies on stress at work and the commitment of the organization have been largely conducted by researchers of the past, mainly in Western countries. This study is conducted keeping in mind the fact that there is lack of studies addressing the issue of stress at work employees of banking sector and organizational commitment in Pakistan. This study is important because of the insights and contributions it offers for the workers in banking sector in Pakistan.

\section{Literature Review and Hypothesis}

In this section, occupational stress, occupational roles stress and organizational commitment has been discussed in depth followed with relevant theories, models and researches. This chapter would give an insight of concepts of occupational stress particularly occupational role stress and organizational commitment and its components like continuance commitment, normative commitment and affective commitment. Occupational stress basically revolves around the concept that physical and mental levels of an employee are affected when discrepancies arise between what is expected from an individual and what he actually delivers (Stănescu, Vasiliu, \& Stoicescu, 2012). Being more specific, it is a condition that arises when employees go through high pressure during their work life that does not match their capabilities (Malik, 2011).

According to Batool (2013) job stress is one of the types of stress where an employee, lacking confidence goes through strenuous situation of hard work and pressure. Bashir and Ramay (2010) has analyzed that stress adversely affects an employee's job satisfaction. Anum (2013) suggests pressure at job only builds up when managers pursue multiple goals at a time, those goals that are not even interlinked with each other. Anum (2013) further goes on saying that according to a study in Malaysia, managers suffering through high depression levels were the ones going through intense work load, working condition and relationship. Relationship and poor working condition have also been claimed as being one of the five major causes of occupational stress (Beheshtifar \& Nazarian, 2013). Responsibility for people is also known to be one of the eleven forces that lead to stress according to researchers (Ahmed \& Ramzan, 2013). Another well known model of effort rewards imbalance discusses the issues associated with work related stress (Siegrist, 2012). The model claims that lack of rewards despite the hard work by an employee contributes to higher stress level and poor health. One of the most popular models known for organization commitment is Mayer and Allen's three component model of organizational commitment. Jaros (2007) describes the model as three simultaneous mindsets that encompasses affective, normative and continuance organizational commitment.

Affective commitment occurs when employees develop thorough ties that get developed with the organization. McMahon (2007) argues that affective commitment comes from positive behaviors at work. Rhoades, Eisenberger, and Armeli (2001) is of the view, company's revenues are strongly linked with affective commitment. There is a strong association between affective commitment, absenteeism and performance. Roxenhall and Andrésen (2012) explains normative commitment as a commitment shown by an employee when he feels a responsibility towards the organization, a responsibility to continue. Those with normative commitment stay in the organization for moral or duty related reasons. Manetje and Martins (2009) argues that organizational commitment that arises due to the individual's assessment on economic benefits gained should be regarded as instrumental attachment towards the organization.

Continuance commitment, also known as calculative commitment occurs when the employee has no other option than to stay. Roxenhall and Andrésen (2012) explains that continuance commitment consists of two different dimensions, negative and positive. In the negative dimension, the committed person who has made investment in time, effort and energy would realize that it may get lost. From Duarte et al. (2013) perception and hypothetical study, it was found that managers in public sector banks had strong affective, normative and continuance commitment. Duarte, used personal variables to assess employee's organizational commitment. Age was found to be one of the important variables as both are interlinked. Gender is another factor associated with 
organizational commitment. In case of women, organizational commitment level is limited to a certain stage after which they consider their family as a main source of their identity and fulfillment. Marital Status has been reported to be another predictor of organizational commitment. Both married and unmarried employee portrays commitment of different levels. Education is one of the essential predictors of organizational commitment. It has a negative relationship with organization commitment because people possessed with low level of education tend to remain in organizational. Thus their commitment levels are seen to be lower than employees who are less educated (Duarte et al., 2013).

\subsection{Occupational Role Stress Model}

According to Boles and Babin (1994) occupational role stress is known to be one of the most commonly researched constructs in organizational behavior. There are around hundred published studies on the topic in the last two decades. Boles and Babin (1994) basically defines role stress having three various aspects known as role ambiguity, role conflict and role overload. Role Stress Model discusses effects of role stressors on a working individual. A role stressor is basically the pressure a working person goes through due to various organizational and job related factors that come in the form of demands and constraints (Idris, 2011). Role Stress theory explains that organizational factors produce role expectations among employees that then generates role pressure. An individual experiencing prolonged pressure would end up suffering from ill health and depression. An employee's performance is heavily affected when they are not clear about the role's authority, responsibility and status. This may lead to stress, dissatisfaction and poor performance. When goals and performance criteria outline to employees are unclear and ambiguous, employees get a perception that their interests are being threatened and this ultimately leads to stress (Idris, 2011).

In literature, one can find relationships between role stressors and feeling of strain. The main cause of strain is the pressure that one suffers from the struggle towards achieving a set of given demands. As previously mentioned, role stressors comprise of three major components known as role overload, role ambiguity and role conflict. Role overload occurs when the expectation from a given position is more than what an individual can actually perform and deliver. Role ambiguity refers to a condition where individuals are uncertain and unclear of what is required from them and how they are to perform the assigned tasks. Role conflict is a state where there are incompatibilities with respect to expectations and demands associated with the role (Idris, 2011).

According to Butt (2009) literature on occupational stress has revealed wide range of reasons of occupational stress and strain that is affected by organizational and individual factors.

The following hypothesis was formulated for this study.

Hypothesis 1: Occupational role stress has significant impact on affective commitment.

Hypothesis 2: Occupational role stress has significant impact on continuance commitment.

Hypothesis 3: Occupational role stress has significant impact on normative commitment.

\section{Methodology}

This research pursues the process of deduction, which is also called "top-down" approach. In this cram, the unit of study is bank employees of Pakistan. Their employment encompasses a variety of services at a time. Working environment of banking sector is very hectic and the job responsibilities are very crucial. The burden of responsibilities and working conditions together contributes to different psychological disturbances. One of the major and common factors that disturbs is occupational stress particularly occupational role stress.

\subsection{Sample and Data}

The facet of analysis was banking industry of Pakistan particularly Karachi was the study where study was conducted. Karachi is the city where banking sector is at its growing stage. There is different classification in banking sector as follows:

- Conventional banking.

- Islamic banking.

The research sample was taken from both the classification of banking industry. It included employees working in both the conventional banking system as well as employees working in Islamic banking system. The reason of focussing in both areas was to come up with more precise and better picture to add to the importance of the study.

The sample size of the participants was 303. The data were collected through random sampling. Simple random sampling is the basic selection process of sampling and is easiest to understand (Frerichs, 2008).

\subsection{Measures}

The organizational commitment questionnaire was used to measure the dependent variable organizational commitment. Organizational Commitment Questionnaire- OCQ is based on the Three-Component Model of Meyer, Allen, and Smith (1993) including affective commitment, continuance commitment, and normative commitment.

The other instrument used was on Organizational Commitment. That included three main parts of organization commitment are normative commitment that included eight items, continuance commitment that included eight items and affective commitment that included eight items.

The Occupational Stress Inventory Revised Edition- OSI-R developed by Osipow (1998) was used to measure occupational stress. The decision to use the OSI-R was largely because of its numerous applications as an instrument and availability of reliability information.

The OSI-R is a self-report inventory consisting of three questionnaires casing all three dimensions of occupational stress. Each of the three is composed of five-point Likert scale items.

The first questionnaire on Occupational Stress Inventory Revised (OSI-R) included three main parts.1.Occupational role stress that included six items.2.Personal strain that included six items.3.Personal resource that included six items. Overall there were eighteen items in occupational stress questionnaire. The 
respondents were asked to rate each of the 18 items in OSI-R and OCQ on the following 5-point Likert scale: 1. strongly disagree, 2. Disagree, 3. Undecided, 4. Agree, 5. strongly agree.

\subsection{Statistical Technique}

First of all pilot testing was done on 40 respondents. The statistical package for social sciences (SPSS-18 Edition) was used to study and analyze the collected data. It was used for the purpose of exploratory analysis. Since this analysis are suitable to test the reliability, factor analysis and relationship between different variables. Another software AMOS, was used for the purpose of confirmatory analysis. In AMOS different techniques like confirmatory factor analysis and Structural equation modeling was performed.

\subsection{Composition of Data}

After univariate and multi variate outlier's analysis. None of univariate outlier was detected and whereas there were 18 multivariate outliers. Therefore sample size was reduced to 285 respondents. Table 1 explains that Reliability analysis was performed on SPSS -18.

Table-1. Reliability analysis after removing 18 outliers.

\begin{tabular}{|c|c|c|c|c|c|}
\hline & & No. of items & Variables & Cranach's Cc & efficient Alpha \\
\hline \multirow[t]{3}{*}{ I.V } & \multirow[t]{3}{*}{ OS } & 6 & Occupational role stress & \multirow{3}{*}{$\begin{array}{l}\text { Alpha of } 18 \\
\text { items }= \\
0.66\end{array}$} & \multirow{6}{*}{$\begin{array}{l}0.72 \\
\text { (42 items) }\end{array}$} \\
\hline & & 6 & Personal strain & & \\
\hline & & 6 & Personal resource & & \\
\hline \multirow[t]{3}{*}{ D.V } & \multirow[t]{3}{*}{$\mathrm{OC}$} & 8 & Affective commitment & \multirow{3}{*}{$\begin{array}{l}\text { Alpha of } 24 \\
\text { items }= \\
0.62\end{array}$} & \\
\hline & & 8 & Continuance commitment & & \\
\hline & & 8 & Normative commitment & & \\
\hline
\end{tabular}

Table-2. KMO and bartlett's test.

\begin{tabular}{|c|c|c|}
\hline \multicolumn{3}{|l|}{ KMO and Bartlett's Test } \\
\hline \multicolumn{2}{|c|}{ Kaiser-Meyer-Olkin Measure of Sampling Adequacy. } & .671 \\
\hline \multirow[t]{3}{*}{ Bartlett's Test of Sphericity } & Approx. Chi-Square & 3614.537 \\
\hline & Df & 861 \\
\hline & Sig. & .000 \\
\hline
\end{tabular}

Table 2 explains that the value of Kaiser -Meyer-Olkin Measure of sampling Adequacy is 0.671 which clearly reflects that there are not sufficient items for each component. A minimum value of 0.70 is suggested by Leech, Barrett, and Morgan (2005).

By performing EFA, there were 14 factors that were loaded. After the analysis it was restricted to 6 factors only. We restrict the factor by "extract" for fixing the number of factors.

Table-3. KMO and Bartlett's Test (for 6 outcome variables).

\begin{tabular}{|c|c|c|}
\hline \multicolumn{3}{|l|}{ KMO and Bartlett's Test } \\
\hline \multicolumn{2}{|c|}{ Kaiser-Meyer-Olkin Measure of Sampling Adequacy. } & .688 \\
\hline \multirow[t]{3}{*}{ Bartlett's Test of Sphericity } & Approx. Chi-Square & 1696.690 \\
\hline & Df & 253 \\
\hline & Sig. & .000 \\
\hline
\end{tabular}

Table 3 explains that the value of KMO Measure of sampling adequacy is now 0.688 which has been improved from 0.671. Varimax orthogonal rotation with Kaiser Normalization extracted "uncorrelated" components. The initial solution was rotated in order to increase the readability of the factor loadings. After rotation six requested components explained approximately $56 \%$ of total variance however, contribution of each component is shown below:

Table-4. Total Variance Explained (six variables).

\begin{tabular}{|c|c|c|c|}
\hline \multicolumn{4}{|c|}{ Total Variance Explained } \\
\hline \multirow[t]{2}{*}{ Component } & \multicolumn{3}{|c|}{ Rotation Sums of Squared Loadings } \\
\hline & Total & \% of Variance & Cumulative \% \\
\hline 1 & 2.877 & 12.510 & 12.510 \\
\hline 2 & 2.870 & 12.477 & 24.987 \\
\hline 3 & 2.128 & 9.254 & 34.241 \\
\hline 4 & 1.828 & 7.948 & 42.190 \\
\hline 5 & 1.767 & 7.683 & 49.872 \\
\hline 6 & 1.484 & 6.452 & 56.324 \\
\hline
\end{tabular}

Table 4 explains that the PCA extracted four components as requested. The research instrument included 42 items. All the 42 items were reduced six components reflecting six measures.

In the Table 5 it is seen that out of 6 items there were 5 items that were loaded in the first component of occupational role. In the second component continuance commitment out of 8 items, there were 6 items loaded. In the third component of personal resource out of 6 items there were 3 items loaded. In the fourth component out of 8 there were 3 items loaded in affective commitment. In the fifth component of personal strain, out of 6 there were 4 items were loaded. In the sixth last component there were 2 items loaded that is of normative commitment out of 8 . 
Table-5. Rotated Component Matrix (outcome variables).

\begin{tabular}{|c|c|c|c|c|c|c|}
\hline & \multicolumn{6}{|c|}{ Component } \\
\hline & 1 & 2 & 3 & 4 & 5 & 6 \\
\hline Alpha & 0.792 & 0.77 & 0.74 & 0.62 & 0.46 & 0.49 \\
\hline $\mathrm{N}$ & 285 & 285 & 285 & 285 & 285 & 285 \\
\hline No. of Items & 5 & 6 & 3 & 3 & 4 & 2 \\
\hline Occprole4 & .826 & & & & & \\
\hline Occprole5 & .796 & & & & & \\
\hline Occprole3 & .781 & & & & & \\
\hline Occprole6 & .763 & & & & & \\
\hline Occprole2 & .519 & & & & & \\
\hline Contcom 15 & & .734 & & & & \\
\hline Contcom 13 & & .728 & & & & \\
\hline Contcom 14 & & .697 & & & & \\
\hline Contcom 11 & & .691 & & & & \\
\hline Contcom 16 & & .637 & & & & \\
\hline Contcom10 & & .603 & & & & \\
\hline Perresource 17 & & & .828 & & & \\
\hline Perresource 18 & & & .799 & & & \\
\hline Perresource 16 & & & .765 & & & \\
\hline Affcom 2 & & & & .767 & & \\
\hline Affcom 1 & & & & .730 & & \\
\hline Affcom3 & & & & .696 & & \\
\hline Perstress 11 & & & & & .690 & \\
\hline Perstress 10 & & & & & .597 & \\
\hline Perstress 8 & & & & & .530 & \\
\hline Perstress9 & & & & & .502 & \\
\hline Norncom19_R & & & & & & .790 \\
\hline Norncom18_R & & & & & & .659 \\
\hline
\end{tabular}

Table-6. Instrument reliability and validity.

\begin{tabular}{|c|c|c|c|c|}
\hline $\begin{array}{l}\text { Latent } \\
\text { constructs }\end{array}$ & Indicators & Items & $\begin{array}{l}\text { Standardized } \\
\text { loading }\end{array}$ & $\begin{array}{l}\text { Reliability } \\
\text { (Alpha,SCR,AVE) }\end{array}$ \\
\hline \multirow[t]{4}{*}{$\begin{array}{l}\text { Occupational } \\
\text { role }\end{array}$} & Occprole6 & $\begin{array}{l}\text { If I make a mistake in my work, the } \\
\text { consequences for others can be pretty bad. }\end{array}$ & .655 & \multirow{4}{*}{$\begin{array}{l}\text { Alpha }=0.792 \\
\mathrm{SCR}=0.82 \\
\mathrm{AVE}=0.54\end{array}$} \\
\hline & Occprole3 & $\begin{array}{l}\text { My supervisors have conflicting ideas about } \\
\text { what I should be doing. }\end{array}$ & .714 & \\
\hline & Occprole5 & $\begin{array}{l}\text { My job requires me to make important } \\
\text { decisions. }\end{array}$ & .801 & \\
\hline & Occprole4 & $\begin{array}{l}\text { I have on the job responsibility for the } \\
\text { activities of other. }\end{array}$ & .777 & \\
\hline \multirow[t]{6}{*}{$\begin{array}{l}\text { Continuance } \\
\text { commitment }\end{array}$} & Contcom 10 & $\begin{array}{l}\text { It would be very hard for me to leave my } \\
\text { organization right now, even if I wanted to. }\end{array}$ & .507 & \multirow{6}{*}{$\begin{array}{l}\text { Alpha }=0.77 \\
\mathrm{SCR}=0.80 \\
\mathrm{AVE}=0.38\end{array}$} \\
\hline & Contcom 16 & $\begin{array}{l}\text { One of the major reasons I continue to work } \\
\text { for this organization is that leaving would } \\
\text { require considerable sacrifice. Another } \\
\text { organization may not match the overall benefit } \\
\text { I have here. }\end{array}$ & .513 & \\
\hline & Contcom 11 & $\begin{array}{l}\text { Too much in my life would be disrupted if I } \\
\text { decided I wanted to leave my organization } \\
\text { now. }\end{array}$ & .591 & \\
\hline & Contcom 14 & $\begin{array}{l}\text { I feel I have too few options to consider leaving } \\
\text { this organization. }\end{array}$ & .764 & \\
\hline & Contcom 13 & $\begin{array}{l}\text { Right now, staying with my organization is a } \\
\text { matter of necessity as much as desire. }\end{array}$ & .648 & \\
\hline & Contcom 15 & $\begin{array}{l}\text { One of the few serious consequences of leaving } \\
\text { this organization would be the scarcity of } \\
\text { available alternatives. }\end{array}$ & .646 & \\
\hline \multirow[t]{3}{*}{$\begin{array}{r}\text { Personal } \\
\text { resources }\end{array}$} & Perresource 16 & $\begin{array}{l}\text { If I need help at work, I know who to } \\
\text { approach. }\end{array}$ & .612 & \multirow{3}{*}{$\begin{array}{l}\text { Alpha }=0.74 \\
\mathrm{SCR}=0.75 \\
\mathrm{AVE}=0.50\end{array}$} \\
\hline & Perresource 18 & $\begin{array}{l}\text { I can establish and stick to my priorities for the } \\
\text { use of my time. }\end{array}$ & .681 & \\
\hline & Perresource 17 & $\begin{array}{l}\text { When faced with a problem I use a systematic } \\
\text { approach. }\end{array}$ & .822 & \\
\hline \multirow[t]{3}{*}{$\begin{array}{l}\text { Affective } \\
\text { commitment }\end{array}$} & Affcom 3 & $\begin{array}{l}\text { I really feel as if this organization's problems } \\
\text { are my own. }\end{array}$ & .611 & \multirow{3}{*}{$\begin{array}{l}\text { Alpha }=0.62 \\
\mathrm{SCR}=0.628 \\
\mathrm{AVE}=0.360\end{array}$} \\
\hline & Affcom 1 & $\begin{array}{l}\text { I would be very happy to spend the rest of my } \\
\text { career with this organization. }\end{array}$ & .557 & \\
\hline & Affcom 2 & $\begin{array}{l}\text { I enjoy discussing my organization with people } \\
\text { outside it. }\end{array}$ & .632 & \\
\hline \multirow[t]{2}{*}{ Personal strain } & Perstress 10 & I find myself complaining about little things. & .515 & \multirow{2}{*}{$\begin{array}{l}\text { Alpha }=0.46 \\
\mathrm{SCR}=0.47 \\
\mathrm{AVE}=0.29\end{array}$} \\
\hline & Perstress 11 & $\begin{array}{l}\text { I quarrel (dispute, hostile feelings) with my } \\
\text { family members including spouse. }\end{array}$ & .575 & \\
\hline \multirow[t]{2}{*}{$\begin{array}{c}\text { Normative } \\
\text { commitment }\end{array}$} & $\begin{array}{l}\text { Norncom18_ } \\
\mathrm{R}\end{array}$ & $\begin{array}{l}\text { I do not believe that a person must always be } \\
\text { loyal to his or her organization. }\end{array}$ & 6.493 & \multirow{2}{*}{$\begin{array}{l}\text { Alpha }=0.49 \\
\mathrm{SCR}=16.08 \\
\mathrm{AVE}=21.07\end{array}$} \\
\hline & $\begin{array}{l}\text { Norncom19_ } \\
\mathrm{R}\end{array}$ & $\begin{array}{l}\text { Jumping from organization to organization } \\
\text { does not seem at all unethical to me. }\end{array}$ & .051 & \\
\hline
\end{tabular}




\subsection{Confirmatory Factor Analysis}

Brown, Harris, O'Quin, and Lane (2017) explains confirmatory factor analysis as simplifying of complexities and tests those constraints. It basically studies how a set of variables are interlinked with latent variables. Multivariate regression model is one of the measurement models that come under Confirmatory factor analysis. In this model, there are two variant known as observed dependent variable and continuous latent variable. The relationship is thus described through set of linear regression equations that work for continuous factor indicators and regression equations are suitable for censored factor indicators.

According to Chau and $\mathrm{Hu}(2001)$ as cited by Lee and Lucey (2010) that scale composite reliability formula is "Square of the summation of the factor loadings) / \{(Square of the summation of the factor loadings $\mathrm{p}$ (summation of error variances)). According to Molina, Lloréns-Montes, and Ruiz-Moreno (2007) the proposed minimum acceptable value is 0.70 . To complete the analysis, the Average Variance Extracted (AVE) is calculated, in which the suggested minimum acceptable value is 0.5 .

Table 6 indicates that the scales are within the acceptable limits and the composite reliability of all latent constructs like occupational role, continuance commitment and personal resource exceeded the benchmark of 0.7, as recommended by Nunnally (1978). This implies that the measurement is good. Table 1 shows the results of convergent validity and internal reliability of constructs.

SEM Correlations

\begin{tabular}{c|c|c|c|c|c|c}
\hline Variable & Occprole & Contcom & Perresourc & Affcom & Perstress & Norncom \\
\hline Occprole & 1.00 & & & & & \\
\hline Contcom & 0.054 & 1.00 & & & & \\
\hline perresourc & 0.149 & 0.052 & 1.00 & & & \\
\hline Affcom & 0.183 & 0.08 & 0.16 & 1.000 & & \\
\hline Perstress & -0.135 & 0.267 & -0.256 & 0.032 & 1.00 & \\
\hline Norncom & 0.007 & -0.029 & 0.036 & 0.003 & -0.039 & 1.00 \\
\hline
\end{tabular}

Hair, Joseph, Ralph, Ronald, and William (1995) the r-value between every pair of independent variables in the correlation should not exceed the 0.9 criterion. If, in any case, the r-value exceeds 0.90 , it is assumed that there is multicollinearity problem. As indicated in Table 7, the highest value of coefficient, namely the occupational role and continuance commitment and personal resource, shows that there is multicollinearity problem among the various constructs in the measurement model (Lin \& Lee, 2004).

Table-8. Latent construct for independent variables only.

\begin{tabular}{c|c|c|c}
\hline Variable & Occprole & Perresourc & Per Strain \\
\hline Occprole & 1.00 & & \\
\hline Perresourc & 0.149 & 1.00 & \\
\hline Per strain & -0.143 & -0.264 & 1.00 \\
\hline
\end{tabular}

Table-9. Measures of model fit

\begin{tabular}{c|c|c|c|c|c|c}
\hline Goodness of fit measures & CMIN/DF & GFI & AGFI & CFI & TLI & RMSEA \\
\hline recommended value & $<3.0$ & $>0.9$ & $>0.90$ & $>0.85$ & $>0.85$ & $<0.08$ \\
\hline CFA Model & 1.92 & 0.909 & 0.875 & 0.894 & 0.869 & 0.057 \\
\hline Structural Model & 1.915 & 0.908 & 0.876 & 0.893 & 0.869 & 0.057 \\
\hline
\end{tabular}

To measure the goodness of fit of the measurement model, six common measures were used. According to Lin and Lee (2004) the common measures are, using the ratio of $\mathrm{x} 2$ statistics to the degree of freedom (Df), comparative fit index (CFI), goodness-of-fit index (GFI), adjusted goodness-of-fit index (AGFI), normed fit index (NFI) and root mean square error of approximation (RMSEA).

As indicated in Table 9, the observed normed $\mathrm{x} 2$ for this model was 1.92, which is smaller than 3 as recommended by Bagozzi and Yi (1988). Other Fit indices such as GFI exceeded the suggested cut-off level of 0.9, whereas here GFI value $=0.909$. Associated to the GFI is the AGFI which adjusts the GFI based upon degrees of freedom, with more saturated models reducing fit (Tabachnick, Fidell, \& Ullman, 2007). AGFI be likely to increase with sample size. As with the GFI, values for the AGFI also range between 0 and 1 and it is commonly accepted that values of 0.90 or greater indicate well-fitting models. Here AGFI value $=0.875$. On the other hand, for CFI and TLI it is $>0.85$ appears to be below the cut-off level of 0.08 as recommended by Browne and Cudeck (1993). The combination of these results suggests that the measurement model appears to represent a very good fit with the data collected. RMSEA; appears to be below the cut-off level of 0.08 as recommended by Browne and Cudeck (1993) here RMSEA = 0.057. The combination of these results suggests that the measurement model appears to represent a very good fit with the data collected. As shown in Table 9, the structural model has a good fit, determined by the Chi-square index: All the model-fit indices exceeded their respective common acceptable levels, suggesting that the structural model portrays an acceptable fit to the data (Browne \& Cudeck, 1993).

\section{Analysis and Results}

Table-10. Showing influence of occupational role stress on affective, continuance and normative commitment.

\begin{tabular}{c|c|c|c|c|c|c}
\hline Hypothesis & Path & $\begin{array}{c}\text { Path Coeff- } \\
\text { Icient }\end{array}$ & $\begin{array}{c}\text { St. } \\
\text { Error }\end{array}$ & $\begin{array}{c}\text { Critical } \\
\text { Ratio }\end{array}$ & P-Value & Remarks \\
\hline H1 & Aff_Commt $\leftarrow$ Occ_role & 0.175 & 0.07 & 2.043 & $0.041^{*}$ & Supported \\
\hline H2 & Con_Commt $\leftarrow$ Occ_role & 0.089 & 0.05 & 1.175 & 0.24 & Not supported \\
\hline H3 & Nor_Commt $\leftarrow$ Occ_role & 0.002 & 0.08 & -0.253 & 0.8 & Not supported \\
\hline
\end{tabular}


To determine the validity of the hypothesized paths, the statistical significance of all the structural parameter values were examined. Hypothesis testing was done through structural equation modeling.

Table 10 shows the results from the analysis implied that Occupational role has significant effect on affective commitment with (path coefficient $=0.175)$. Occupational role has insignificant effect on continuance commitment with (path coefficient $=0.089$ ), Occupational role has insignificant effect on normative commitment with (path coefficient $=-0.002)$, Personal resource has significant effect on affective commitment with (path coefficient= 0.164),Personal resource has insignificant effect on continuance commitment with (path coefficient=0.135),Personal resource has significant effect on normative commitment with (path coefficient $=0.021$ ), Personal strain has insignificant effect on affective commitment with (path coefficient $=0.114$ ),Personal strain has significant effect on continuance commitment with (path coefficient=0.383),Personal strain has significant effect on normative commitment with (path coefficient=0.037).

\section{Discussion}

In light of the observational aftereffects of this study, after are the explanations for the examination questions: 1. Relationship between occupational role stress and affective commitment.

2. Relationship between occupational role stress and continuance commitment.

3. Relationship between occupational role stress and normative commitment.

To answer the first research question it was conjectured that there was a strong relationship between occupational role stress and job responsibility. To break down this relationship, three sub-divisions of organizational commitment have been tested. Employees were analyzed for their affective commitment, continuance commitment and normative commitments. Results of regression analysis shows that there is a positive or significant relationship between occupational role stress and affective commitments of employees with path coefficient $=0.175$, which implied that higher score on occupational role stress prompted lower score on affective occupational commitment of the Bank representatives.

It was likewise discovered that the way of association additionally influenced the relationship between occupational role stress and other two types of occupational commitments i.e. continuance and normative commitments of employees. The level of significance for employees working in banking sectors of Pakistan was found to be insignificant i.e. 0.089 for continuance and -0.002 for normative commitment, which implied that representatives working in administration conveyance associations have lower occupational role stress and resultantly have higher normative and continuance responsibility. These results approved that there is an opposite relationship between occupational role stress and normative and continuance commitment as compared to affective job responsibility of employees.

These results are steady with the aftereffects of various studies referred to by Bishop, Scott, and Burroughs (2000) who suggested that there is a negative relationship between occupational role stress and normative and continuance occupational commitment. They completed a study on the relationship of identity attributes with occupational role stress and employees' commitment towards organization among the college instructors in Pakistan. A huge negative correspondence was found between occupational role stress and these two types of occupational commitment. Like job role of employees, other demographic variables of age, sexual orientation, conjugal status, capability, pay, sort of livelihood, encounter, and working additional hours critical corresponded with identity, stress and authoritative responsibility and helped fundamentally to push and duty.

These findings are in agreement with Michael, Court, and Petal (2009) research who proved that job role stress negatively influences the affective commitment. Accordingly, during stressful periods, employee at management positions put their emotions aside and focuses on the tasks they need to perform. Conversely, when the stress level decreases, affective commitment tends to increase. Our results support as well Browne and Cudeck (1993) findings that there is a strong inverse relationship between commitment and intention to leave. Consequently, high levels of role conflict and role ambiguity (work stressors) make the employees perceive the company as unsupportive, thus their affective commitment decreases. Our findings are in agreement as well with Yousef (2002); Irving and Coleman (2003) and Meyer, Stanley, Herscovitch, and Topolnytsky (2002) a negative relationship exists between affective commitment and role conflict and role ambiguity.

Fineman and Payne (1981) did a study on law requirement and social insurance experts on occupational commitment and occupational role stress. They discovered a huge relationship between occupational role stress and occupational commitment. People who have just started their career and who did not have sufficient training or instruction to perform their employments were less dedicated to their occupation. People, who had issues with work quality, had poor demeanor towards work or demonstrated lower employees' commitment towards organization. People who accomplished an abnormal state of part clash and equivocalness likewise diminished their level of occupational commitment.

The conceivable purpose behind the substantial turnover of workers in Banks in Pakistan could be the consequence of the profoundly distressing nature's turf, which puts strain on the representatives heading subsequently to lower occupational commitment and high turnover. Hence, the study results make that there is a converse relationship between occupational role stress and employees' commitment towards organization in the Bank division in Pakistan.

\section{Conclusion}

It was hypothesized in this research work that occupational role stress has significant impact on affective commitment, continuance commitment, and normative commitment. The hypotheses of research are accepted; however, the primary data analysis rejects the hypothesis that says occupational role stress has significant effects on continuance and normative commitment. 


\section{Managerial Implication}

This study could help the management to use the research results to develop appropriate strategies to address formulate the stress-related problems of their employees. Researching in banking sector of Pakistan will be a unique combination to the study.

\section{Limitations and Area of Further Study}

The research methodology adopted for this research has certain limitations which should be taken into consideration if any generalizations or conclusions are to be drawn from the research findings. The data was collected through survey questionnaires using the quantitative approach. This approach has some limitations including the fact that standardized questionnaires impose restrictions on the depth of data, which can be collected about the phenomenon under investigation. Moreover, standardized questionnaires reflect the opinions and perceptions of only those who choose to respond.

The results from this study have created possibilities for future research. For future organizational commitment and occupation role stress would need to be studied in depth. More demographic, psychological and social variables like age, experience and pay would need to be linked with occupational stress and organizational commitment. Many researchers are of the view that longitudinal studies are required as it provide a more in depth insight to the outcomes of these factors on different forms of occupational stress and organizational commitment.

Khan, Ramzan, and Butt (2013) further suggests that close examination needs to be carried out on different occupational groups as all are not same. Differences are found that have an impact on the result of the study. For instance level of occupational stress found in employees working in the service sector is different than of those working in an office environment. Different have not just been found in organizational group but has also been found in gender. For instance level of organizational commitment levels vary among males and females. Here additional research needs to be carried out in work environment, culture, employment terms, occupational advancement and benefits among both genders to get a better insight of the consequences that occupational stress and organizational commitment. Qualititative studies here play an important part because of the varying culture and working environment. A qualitative study can provide a better idea on the level of occupational stress and organizational commitment employees have towards the organization.

\section{References}

Ahmed, A., \& Ramzan, M. (2013). Effects of job stress on employees job performance a study on banking sector of Pakistan. IOSR Journal of Business and Management, 11(6), 61-68. Available at: https://doi.org/10.9790/487x-1166168.

Anum, K. M. R. (2013). Is job satisfaction of islamic banks operational staff determined through organizational climate, occupational stress, age and gender. Journal of Business Studies Quarterly, 16-17.

Bagozzi, R. P., \& Yi, Y. (1988). On the evaluation of structural equation models. Journal of the Academy of Marketing Science, 16(1), 74-94.

Bashir, U., \& Ramay, M. (2010). Impact of stress on employees job performance a study on banking sector of Pakistan. International Journal of Marketing Studies, 2(1), 122-126. Available at: https://doi.org/10.5539/ijms.v2n1p122.

Batool, S. (2013). Developing organizational commitment and organizational justice to amplify organizational citizenship behavior in banking sector. Pakistan Journal of Commerce and Social Sciences, 7(3), 646-655.

Beheshtifar, M., \& Nazarian, R. (2013). Role of occupational stress in organizations. Interdisciplinary Journal of Contemporary Research in Business, $4(9), 648-657$

Bishop, J. W., Scott, K. D., \& Burroughs, S. M. (2000). Support, commitment, and employee outcomes in a team environment. Journal of Management, 26(6), 1113-1132. Available at: https://doi.org/10.1177/014920630002600603.

Boles, J. S., \& Babin, B. J. (1994). Role stress revisited: One or two constructs? Journal of Marketing Theory and Practice, 2(3), 57-69. Available at: https://doi.org/10.1080/10696679.1994.11501659.

Brown, G. T., Harris, L. R., O'Quin, C., \& Lane, K. E. (2017). Using multi-group confirmatory factor analysis to evaluate cross-cultural research: Identifying and understanding non-invariance. International Journal of Research $\mathcal{F}^{\circ}$ Method in Education, 40(1), 66-90. Available at: https://doi.org/10.1080/1743727x.2015.1070823.

Browne, M. W., \& Cudeck, R. (1993). Alternative ways of assessing model fit. Newbury Park, CA: Sage Publications.

Butt, Z. U. (2009). The relationship between occupational stress and organization commitment in non governmental organizations of Pakistan. 17-170.

Cartwright, S., \& Cooper, C. L. (1997). Managing workplace stress. USA: Sage Publication, Inc.

Chau, P. Y., \& Hu, P. J. H. (2001). Information technology acceptance by individual professionals: A model comparison approach. Decision Sciences, 32(4), 699-719. Available at: https://doi.org/10.1111/j.1540-5915.2001.tbo0978.x.

Duarte, M., Sabharwal, A., Aggarwal, V., Jana, R., Ramakrishnan, K. K., Rice, C. W., \& Shankaranarayanan, N. K. (2013). Design and characterization of a full-duplex multiantenna system for WiFi networks. IEEE Transactions on Vehicular Technology, 63(3), 11601177. Available at: https://doi.org/10.1109/tvt.2013.2284712.

Fineman, S., \& Payne, R. (1981). Role stress-a methodological trap? Journal of Organizational Behavior, 2(1), 51-64. Available at: https://doi.org/10.1002/job.4030020105.

Frerichs, J. E. F. (2008). The impact of No Child Left Behind (NCLB) on parent involvement in selected East Tennessee Title I schools: A mixed methods study.

Hair, J., Joseph, F., Ralph, E. A., Ronald, L. T., \& William, C. (1995). Multivariate data analysis: Macmillan.

Hashmi, M. S., \& Naqvi, I. H. (2012). Investigating organizational commitment as the outcome of job satisfaction: A study of banking sector of Pakistan. International Journal of Learning \& Development, 2(4), 146-154. Available at: https://doi.org/10.5296/ijld.v2i4.2077.

Idris, M. K. (2011). Over time effects of role stress on psychological strain among Malaysian public university academics. International Journal of Business and Social Science, 2(9), 154-161.

Irving, P. G., \& Coleman, D. F. (2003). The moderating effect of different forms of commitment on role ambiguity-job tension relations. Canadian Journal of Administrative Sciences, 20(2), 97-106. Available at: https://doi.org/10.1111/j.1936-4490.2003.tbo0696.x.

Jaros, S. (2007). Meyer and Allen model of organizational commitment: Measurement issues. The Icfai Journal of Organizational Behavior, $6(4), 7-25$.

Khan, A., Ramzan, M., \& Butt, M. S. (2013). Is job satisfaction of Islamic banks operational staff determined through organizational climate, occupational stress, age and gender. Journal of Business Studies Quarterly, 4(3), 13.

Kobasa, S. C., \& Antrosrusky. (1998). Commitment and coping strategies in stress resistance among lawyers. Journal of Personality and Social Psychology, 42(4), 707-717. Available at: https://doi.org/10.1037/0022-3514.42.4.707.

Lee, W., \& Lucey, J. (2010). Formation and physical properties of yogurt. Asian-Australasian Journal of Animal Sciences, $23(9)$, $1127-1136$. Available at: https://doi.org/10.5713/ajas.2010.r.05.

Leech, N. L., Barrett, K. C., \& Morgan, G. A. (2005). SPSS for intermediate statistics: Use and interpretation: Psychology Press.

Lin, H.-F., \& Lee, G.-G. (2004). Perceptions of senior managers toward knowledge-sharing behaviour. Management Decision, 42(1), $108-125$.

Malik, N. (2011). A study on occupational stress experienced by private and public banks employees in Quetta City. African Journal of Business Management, 5(8), 3063-3070. 
Manetje, O., \& Martins, N. (2009). The relationship between organisational culture and organisational commitment. Southern African Business Review, 13(1), 87-111.

McMahon, B. (2007). Organizational commitment, relationship commitment and their association with attachment style and locus of control. Doctoral Dissertation, Georgia Institute of Technology.

Meyer, J. P., Allen, N. J., \& Smith, C. A. (1993). Commitment to organizations and occupations: Extension and test of a three-component conceptualization. Journal of Applied Psychology, 78(4), 538-551. Available at: https://doi.org/10.1037/0021-9010.78.4.538.

Meyer, J. P., Stanley, D. J., Herscovitch, L., \& Topolnytsky, L. (2002). Affective, continuance, and normative commitment to the organization: A meta-analysis of antecedents, correlates, and consequences. Journal of Vocational Behavior, 61(1), 20-52. Available at: https://doi.org/10.1006/jvbe.2001.1842.

Michael, O., Court, D., \& Petal, P. (2009). Job stress and organizational commitment among mentoring coordinators. International Journal of Educational Management, 23(3), 266-288. Available at: https://doi.org/10.1 108/09513540910941766.

Molina, L. M., Lloréns-Montes, J., \& Ruiz-Moreno, A. (2007). Relationship between quality management practices and knowledge transfer. Journal of Operations Management, 25(3), 682-701. Available at: https://doi.org/10.1016/j.jom.2006.04.007.

Nunnally, J. C. (1978). Psychometric theory (2nd ed.). New York: McGraw-Hill.

Osipow, S. H. (1998). Occupational stress inventory, revised edition (OSI-R): Psychological Assessment Resources, Incorporated.

Rhoades, L., Eisenberger, R., \& Armeli, S. (2001). Affective commitment to the organization: The contribution of perceived or ganizational support. Journal of Applied Psychology, 86(5), 825-836. Available at: https://doi.org/10.1037/002 1-9010.86.5.825.

Roxenhall, T., \& Andrésen, E. (2012). Affective, calculative and normative commitment: An assesment of relationship. World Revierw of Business Research, 2(5), 86-96.

Siegrist, J. (2012). Effort-reward imbalance at work: Theory, measurement and evidence (Vol. 19): Department of Medical Sociology, University Düsseldorf, Düsseldorf.

Stănescu, M., Vasiliu, A. M., \& Stoicescu, M. (2012). Occupational stress in physical education and sport area. Procedia - Social and Behavioral Sciences, 33, 218-222. Available at: https://doi.org/10.1016/j.sbspro.2012.01.115.

Tabachnick, B. G., Fidell, L. S., \& Ullman, J. B. (2007). Using multivariate statistics (Vol. 5, pp. 481-498). Boston, MA: Pearson.

Yousef, D. A. (2002). Job satisfaction as a mediator of the relationship between role stressors and organizational commitment: A study from an Arabic cultural perspective. Journal of Managerial Psychology, 17(4), 250-266. Available at: https://doi.org/10.1108/02683940210428074. 